\title{
Diversity of Calliphoridae and Sarcophagidae (Diptera, Oestroidea) in continuous forest and gaps at different stages of regeneration in the Urucu oilfield in western Brazilian Amazonia
}

\author{
José Roberto Pereira de Sousa ${ }^{1,2}$, Maria Cristina Esposito² \& Fernando da Silva Carvalho Filho²
}

\begin{abstract}
' Departamento de Química e Biologia, Centro de Estudos Superiores de Imperatriz, Universidade Estadual do Maranhão. Rua Godofredo Viana 1300, Bairro União, 65901-430 Imperatriz-MA, Brasil. jrszoo@hotmail.com

${ }_{2}^{2}$ Programa de Pós-Graduação em Zoologia, Universidade Federal do Pará, Instituto de Ciências Biológicas. Rua Augusto Correa, s/n, Caixa Postal: 8607,66.074-150 Belém-PA.jrszoo@hotmail.com; esposito@ufpa.br; fernanbio@yahoo.com.br
\end{abstract}

\begin{abstract}
Diversity of Calliphoridae and Sarcophagidae (Diptera, Oestroidea) in continuous forest and gaps at different stages of regeneration in the Urucu oilfield in western Brazilian Amazonia. The diversity of Calliphoridae and Sarcophagidae in continuous forest and gaps at different stages of regeneration was studied in the Urucu river basin, in Coari, state of Amazonas, Brazil. The flies were collected at 16 sampling points, 12 in gaps at different stages of regeneration (early $-\mathrm{C} 1$, mid- $\mathrm{C} 2$ and late successional - C3) and four in continuous forest - MT. The diversity of blowflies was similar in the two less regenerated habitats (C1 and C2), and lower than that in the late successional (C3) and continuous forests (MT). By contrast, the diversity of flesh flies was much higher in all three types of gaps (C1, C2 and C3) in comparison with continuous forest (MT). Ordination (NMDS) and similarity (ANOSIM) analyses revealed that the blowflies communities were grouped by habitat type, which affected species composition more than diversity. Analysis of the flesh flies revealed two main groupings, gaps (C1, C2 and C3) and continuous forest (MT), with no evidence of any influence of successional stage on the diversity of the community.
\end{abstract}

KEYWORDS. Anthropogenic impacts; blowflies; community ecology; flesh flies; Neotropical region.

RESUMO. Diversidade de Calliphoridae e Sarcophagidae (Diptera, Oestroidea) em florestas contínuas e clareiras com diferentes estágios de regeneração no campo petrolífero Urucu no oeste da Amazônia brasileira. A diversidade de Calliphoridae e Sarcophagidae em florestas contínuas e clareiras com diferentes estágios de regeneração foi avaliada na bacia do Rio Urucu, Coari, Estado do Amazonas, Brasil. As moscas foram coletadas em 16 áreas amostrais, 12 de clareira, em diferentes estágios de regeneração (pouco recuperadas $-\mathrm{C} 1$, semi-recuperadas $-\mathrm{C} 2$, bem recuperadas $-\mathrm{C} 3$ ) e quatro em floresta contínua - MT). A diversidade de Calliphoridae foi similar nos dois habitats menos recuperados $(\mathrm{C} 1$ e $\mathrm{C} 2)$, sendo menores do que as dos habitats de clareiras bem recuperadas (C3) e florestas contínuas (MT). Entretanto, a diversidade de Sarcophagidae foi muito maior nos três tipos de clareiras (C1, C2 e C3) quando comparada com a floresta contínua (MT). As análises de ordenação (NMDS) e de similaridade (ANOSIM) demonstraram que as comunidades de Calliphoridae foram agrupadas conforme os quatro tipos de ambientes, e que a composição de espécies foi mais afetada do que a diversidade. A análise de Sarcophagidae revelou a formação de dois grupos, clareiras (C1, C2 e C3) e florestas contínuas (MT), sem evidência de qualquer influencia dos estágios de recuperação das clareiras sobre a diversidade da comunidade.

PALAVRAS-CHAVE. Ecologia de comunidade; califorídeos; impactos antrópicos; região Neotropical; sarcofagídeos.

Many studies of ecological diversity have shown that among-habitat comparisons of the homogeneity or heterogeneity in species composition are essential for the understanding and monitoring of both natural and anthropogenic impacts on the biota of a given area (Lawton et al. 1998; Moreno \& Halffter 2001; Magurran 2004; Marinoni \& Ganho 2006).

The blowflies (Calliphoridae) and flesh flies (Sarcophagidae) are sarcosaprophagous dipterans, which develop in carcasses, feces, and other types of organic material (Triplehorn \& Johnson 2011). The response of these flies to the effects of anthropogenic impacts on the environment has been studied by Centeno et al. (2004), Esposito et al. (2009, 2010), Ferraz et al. (2009), and Sousa et al. (2010; 2011). These studies have shown that the species richness and diversity of blowflies decrease in areas that have suffered anthropogenic impact, in comparison with natural environments. According to Sousa et al. (2010) this reduction in species richness may be related primarily to the disappearance of species less tolerant of such impact, and the increasing dominance of species better adapted to anthropogenic conditions.

The area around Porto Urucu in Coari, located in the Brazilian state of Amazonas, is characterized by dense non-flooded forest with higher canopy, and including numerous forest clearings at varying stages of regeneration (Lima \& Rosário 2008). The present study is based on the hypothesis that the diversity of both blow- and flesh flies will be higher in the better-preserved habitats, i.e. continuous forest and gaps at an advanced stage of regeneration, than in those with reduced vegetation cover. In this context, the objective of the study was to evaluate differences in the diversity of flies of the families Calliphoridae and Sarcophagidae in habitats representing varying degrees of impact - from early, mid, and late successional gaps to continuous forest - in the region of Porto Urucu. 


\section{MATERIAL AND METHODS}

Study area. The data were collected at the Base Operacional Geólogo Pedro de Moura (BOGPM) in the Petrobrás S.A. oilfield in the Urucu River basin, in the municipality of Coari, in the Brazilian state of Amazonas. The study area is located approximately $600 \mathrm{~km}$ west of the state capital, Manaus, between the parallels 4 $51^{\prime} 18^{\prime \prime}$ and 4'52'16'S, and the meridians $65^{\circ} 17^{\prime} 58^{\prime \prime}$ and $65^{\circ} 20^{\prime} 01^{\prime \prime} \mathrm{W}$, at an altitude of $60-70 \mathrm{~m}$ above sea level, and with a total area of 514,000 hectares.

A total of 16 sampling points were selected, of which 12 were located in forest gaps representing different stages of regeneration, based on the height of the vegetation $(\mathrm{C} 1, \mathrm{C} 2$ and $\mathrm{C} 3$ ), and the remaining four in continuous primary forest - MT, as described for Sousa et al (2011). The site description and collecting method were published in Sousa et al. (2011).

Data analysis. The alpha $(\alpha)$ diversity was analyzed using the Shannon-Wiener ( $H^{\prime}$ '), equitability (Shannon J'), and Simpson's dominance (D) indices. Magurran (2004) presented a detailed description of these indices. The combined application of these different indices is considered by some authors, such as Ovreas \& Torsvik (1998) and Staddon et al. (1997), to be a useful complementary approach for a better understanding of both the diversity and the structure of communities. Barrantes \& Sandoval (2009) said that the implementation of different statistical methods will allow testing particular hypotheses on patterns of species richness and species abundance among communities. The indices were calculated using Biodiversity Pro 2.0 (McAleece et al.1997).

The $\alpha$ diversity (Simpson's D) was compared among habitats using a one-way analysis of variance, or ANOVA (Zar 1999), run in BioEstat 5.0 (Ayres et al. 2007), considering a $\mathrm{p}<0.05$ significance level. The normality of the data was evaluated $a$ priori using the Lilliefors test for $k$ samples (Ayres et al. 2007). Simpson's D has been used in many ecological studies, and was chosen for this analysis due to its potential to demonstrate the "concentration" of dominance within the community, given that the larger the value, the greater the dominance of one or a few species. Basically, this index expresses the relative abundance of the most common species, and is thus more sensitive to changes in the abundance of these species (Magurran 2004).

The beta $(\beta)$ diversity of blow flies and flesh flies between points was evaluated using Jaccard's index of similarity $(\mathrm{IJ}): \mathrm{IJ}=(\mathrm{c}) /(\mathrm{a}+\mathrm{b}+\mathrm{c}) * 100$, where $\mathrm{c}=$ the number of species found in both habitats, and $\mathrm{a}$ and $\mathrm{b}$ are the number of species found exclusively in habitats a and $b$, respectively. This index is appropriate for the comparison of the species composition of communities (Magurran 2004).

In order to evaluate the $\beta$ diversity of blow flies and flesh flies among habitats, the presence/absence of each species was analyzed using non-metric multidimensional scaling (NMDS), using the Bray-Curtis index as a measure of similarity (Legendre \& Legendre 1998). The distortion of the resolution of the ordination in two dimensions is represented by a stress value $(\mathrm{S})$. The closer this value is to zero, the better the original distances are represented in the final arrangement (Legendre \& Legendre 1998).

Differences among habitats were evaluated using an analysis of similarity (ANOSIM). In this analysis, the closer the global $\mathrm{R}$ value is to the maximum (1), the less likely the distribution is random, in other words, the greater the probability that the communities are different (Clarke 1993). For this analysis, the significance level was $\mathrm{p}<0.001$. The ANOSIM was run in the PAST program (Hammer et al. 2001), while the NMDS was produced by Primer, version 5 (Clarke \& Gorley 2001).

\section{RESULTS AND DISCUSSION}

Alpha ( $\boldsymbol{\alpha})$ diversity of the Calliphoridae. A total of 7,215 blow flies, belonging to three subfamilies, eight genera and 16 species, were collected at the 16 sampling points distributed among the four habitats, as described for Sousa et al. (2010). The $\alpha$ diversity for each point, as represented by the Shannon-Wiener ( $\left.H^{\prime}\right)$, equitability (Shannon's J') and dominance (Simpson's D) indices, is described in Table I. In general, the points in habitats $\mathrm{C} 1$ and $\mathrm{C} 2$ were the least diverse (Fig. 1), according to all three indices, while those in $\mathrm{C} 3$ and MT habitats were the most diverse. The results of the ANOVA indicated significant differences in diversity (D) among habitats $(\mathrm{F}=8.418$, d.f. $=3, \mathrm{p}=0.0031)$, and the a posteriori test identified significant differences $(\mathrm{p}<0.01)$ between habitats MT and C1, and MT and C2 (Table II).

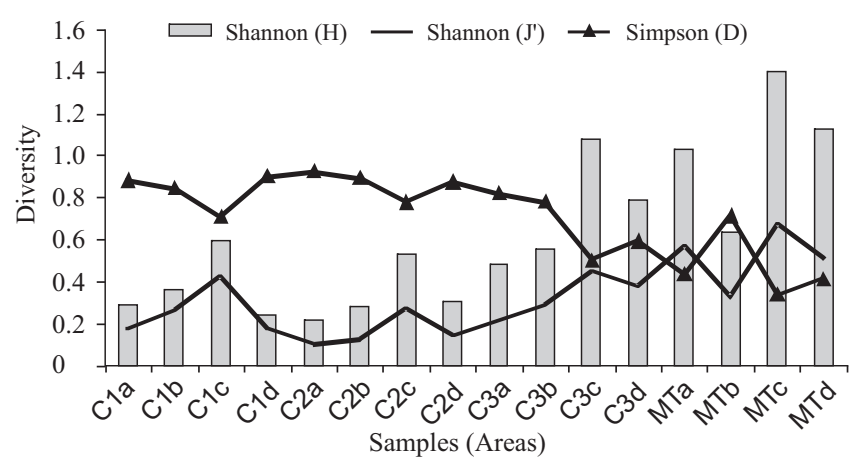

Fig. 1. Diversity of blowflies at the 16 sample points in the Urucu oilfield in Coari, Amazonas, Brazil.

The higher diversity recorded in habitats MT and C3 is related to the higher species richness and lower species dominance recorded in these environments. In the same area, Sousa et al. (2010) also recorded a higher species richness of blow flies in the better-preserved habitats, and that Mesembrinella batesi (Aldrich, 1922), M. bicolor (Fabricius, 1805) and Hemilucilia segmentaria (Fabricius, 1805) were exclusive to the late successional and continuous forest.

Beta $(\boldsymbol{\beta})$ diversity of the Calliphoridae. The Jaccard indices (Table III) indicate, in general, a greater similarity of 
Table I. Diversity indices for the blowflies (Calliphoridae) and flesh fly (Sarcophagidae) communities at each of the 16 sampling points surveyed at the Urucu basin oilfield in Coari, Amazonas, Brazil.

\begin{tabular}{lcccccccc}
\hline \multirow{2}{*}{ Sampling } & \multicolumn{3}{c}{ Calliphoridae } & & \multicolumn{3}{c}{ Sarcophagidae } \\
\cline { 2 - 3 } \cline { 7 - 8 } & $\begin{array}{c}\text { Shannon } \\
(\mathrm{H})\end{array}$ & $\begin{array}{c}\text { Shannon } \\
\left(\mathrm{J}^{\prime}\right)\end{array}$ & $\begin{array}{c}\text { Simpson } \\
(\mathrm{D})\end{array}$ & & $\begin{array}{c}\text { Shannon } \\
(\mathrm{H})\end{array}$ & $\begin{array}{c}\text { Shannon } \\
(\mathrm{J})\end{array}$ & $\begin{array}{c}\text { Simpson } \\
(\mathrm{D})\end{array}$ \\
\hline (C1a) & 0.286 & 0.177 & 0.880 & & 1.604 & 0.669 & 0.298 \\
$(\mathrm{C} 1 \mathrm{~b})$ & 0.363 & 0.262 & 0.845 & & 1.522 & 0.661 & 0.325 \\
$(\mathrm{C} 1 \mathrm{c})$ & 0.592 & 0.427 & 0.710 & & 1.742 & 0.726 & 0.237 \\
$(\mathrm{C} 1 \mathrm{~d})$ & 0.242 & 0.175 & 0.900 & & 1.574 & 0.716 & 0.284 \\
$(\mathrm{C} 2 \mathrm{a})$ & 0.217 & 0.104 & 0.923 & & 1.68 & 0.700 & 0.296 \\
$(\mathrm{C} 2 \mathrm{~b})$ & 0.281 & 0.128 & 0.893 & & 1.574 & 0.656 & 0.322 \\
$(\mathrm{C} 2 \mathrm{c})$ & 0.530 & 0.272 & 0.776 & & 1.792 & 0.747 & 0.239 \\
$(\mathrm{C} 2 \mathrm{~d})$ & 0.307 & 0.147 & 0.874 & & 1.515 & 0.59 & 0.349 \\
$(\mathrm{C} 3 \mathrm{a})$ & 0.480 & 0.218 & 0.821 & & 1.715 & 0.69 & 0.262 \\
$(\mathrm{C} 3 \mathrm{~b})$ & 0.556 & 0.286 & 0.78 & & 1.901 & 0.825 & 0.187 \\
$(\mathrm{C} 3 \mathrm{c})$ & 1.079 & 0.450 & 0.502 & & 1.859 & 0.748 & 0.205 \\
$(\mathrm{C} 3 \mathrm{~d})$ & 0.788 & 0.379 & 0.591 & & 1.327 & 0.517 & 0.417 \\
$(\mathrm{MTa})$ & 1.027 & 0.573 & 0.434 & & 1.028 & 0.741 & 0.421 \\
$(\mathrm{MTb})$ & 0.633 & 0.325 & 0.712 & & 0.536 & 0.488 & 0.708 \\
$(\mathrm{MTc})$ & 1.398 & 0.672 & 0.34 & & 0.883 & 0.637 & 0.523 \\
$(\mathrm{MTd})$ & 1.122 & 0.51 & 0.413 & & 1.088 & 0.607 & 0.459 \\
\hline & & & & & &
\end{tabular}

Table II. Results of the ANOVA and Student-Newman-Keuls post-test for the comparison of dominance indices (Simpson's D) for the Calliphoridae and Sarcophagidae communities surveyed in four environments types in the Urucu oilfield, Coari, Amazonas. The values in bold type are significant at the $\alpha<0.05$ level.

\begin{tabular}{cccccc}
\hline Family & $\mathrm{F}$ & $\begin{array}{c}\text { Degrees of } \\
\text { freedom }\end{array}$ & $\mathrm{P}$ & $\begin{array}{c}\text { Student-Newman-Keuls } \\
\text { comparison }\end{array}$ & $\mathrm{p}$ \\
\hline Calliphoridae & 8.418 & 3 & 0.0031 & $\mathrm{C} 1-\mathrm{C} 2$ & $\mathrm{~ns}$ \\
& & & $\mathrm{C} 1-\mathrm{C} 3$ & $\mathrm{~ns}$ \\
& & & $\mathrm{C} 1-\mathrm{MT}$ & $<0.01$ \\
& & & $\mathrm{C} 2-\mathrm{C} 3$ & $\mathrm{~ns}$ \\
& & & $\mathrm{C} 2-\mathrm{MT}$ & $<0.01$ \\
\hline Sarcophagidae & 7.7731 & 3 & 0.0041 & $\mathrm{C} 3-\mathrm{MT}$ & $\mathrm{ns}$ \\
& & & & $\mathrm{C} 1-\mathrm{C} 2$ & $\mathrm{~ns}$ \\
& & & $\mathrm{C} 1-\mathrm{C} 3$ & $\mathrm{~ns}$ \\
& & & $\mathrm{C} 2-\mathrm{CT}$ & $<0.01$ \\
& & & $\mathrm{C} 2-\mathrm{MT}$ & $\mathrm{ns}$ \\
& & & $\mathrm{C} 3-\mathrm{MT}$ & $<0.01$ \\
\hline
\end{tabular}

blowfly communities within habitats than between them. The NMDS plot (Fig. 2) showed a clear differentiation between the four habitat types. In this plot, habitats MT and C1 were well-separated, while habitats $\mathrm{C} 1$ and $\mathrm{C} 2$, on the one hand, and $\mathrm{C} 3$ and $\mathrm{MT}$, on the other, presented a certain affinity. The global R value for the ANOSIM (0.617) was highly significant $(\mathrm{p}<0.001)$, confirming the differences among habitats (Table IV).

In general, the composition of the blowflies fauna varied among the habitats surveyed, as indicated by the ordination analysis. In this analysis, the formation of two groups - C1/ $\mathrm{C} 2$ and $\mathrm{C} 3 / \mathrm{MT}$ - reflects the differences in the adaptive ca-

\&ิ)

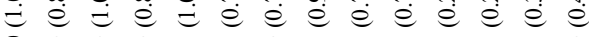

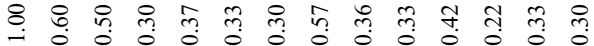

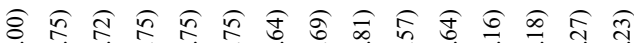

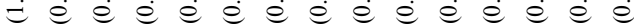

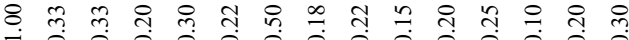

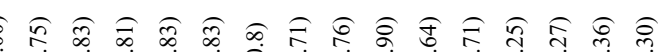
e e e e e e e e e e e e e e e

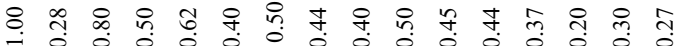

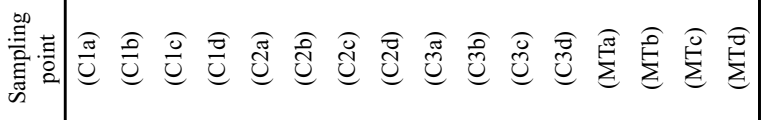




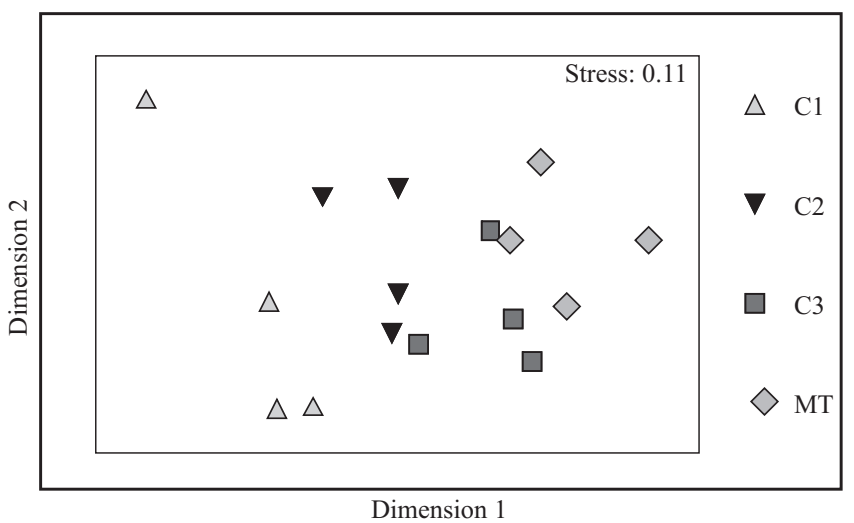

Fig. 2. Non-metric multidimensional scaling (NMDS) of the species composition of the blowflies communities at 16 sampling points located in the Urucu oilfield, representing four habitat types $(\mathrm{C} 1, \mathrm{C} 2, \mathrm{C} 3$, and $\mathrm{MT})$.

Table IV. Results of analyses of similarity (ANOSIM) for the comparison of the Calliphoridae and Sarcophagidae (in parentheses) communities in four environments types in the Urucu basin oilfield, Coari, Amazonas. The $r$ values indicate the level of similarity between pairs of habitats or across all sites (global R). The values in bold represent the smallest distances between environments for the blowflies (C1-C2 and C3-MT), and flesh flies (C1-C2, C1-C3 and C2-C3).

\begin{tabular}{ccccc}
\hline Environments & $\mathrm{C} 1$ & $\mathrm{C} 2$ & $\mathrm{C} 3$ & $\mathrm{MT}$ \\
\hline $\mathrm{C} 1$ & $0(0)$ & & & \\
$\mathrm{C} 2$ & $\mathbf{0 . 5 3 6 5 ( - \mathbf { 0 . 0 4 1 6 7 } )}$ & $0(0)$ & & \\
C3 & $0.6146(\mathbf{0 . 0 0 5 2 0 2})$ & $0.5469(\mathbf{- 0 . 0 8 8 5 4})$ & $0(0)$ & \\
MT & $1(0.9688)$ & $0.9896(0.9792)$ & $\mathbf{0 . 2 8 6 5}(0.9688)$ & $0(0)$ \\
\hline
\end{tabular}

pacity of the family, given that, for some species such as the Mesembrinellinae, habitat characteristics may determine range limits. Overall, the differences among the habitats was demonstrated more clearly by the similarity index than the diversity parameter, indicating that it is the composition of species, rather than simply the number of taxa, that is most affected by alterations to the environment.

The alpha $(\alpha)$ diversity of the Sarcophagidae. A total of 3,547 flesh flies were collected at the 16 collecting points, of which, 3,525 specimens were identified to the species level, as described for Sousa et al. (2011). In all, 23 species were identified, distributed in 10 genera and six subgenera. The indices defining the $\alpha$ diversity of this group are shown in Table I. In general, the samples from the continuous forest presented the lowest diversity $\left(H^{\prime}\right)$, and the highest dominance (D), while all the gaps presented relatively high levels of diversity (Fig. 3). The results of the ANOVA indicated significant differences in diversity (D) among habitats ( $\mathrm{F}=$ 7.773 , d.f. $=3, \mathrm{p}=0.004$ ), and the a posteriori test identified significant differences between continuous forest and all three categories of gaps: $\mathrm{C} 1(\mathrm{p}<0.01), \mathrm{C} 2(\mathrm{p}<0.05)$ and $\mathrm{C} 3, \mathrm{p}<$ 0.01 (Table II). Overall, then, the gaps are characterized by high levels of diversity, and are more similar to one another than to the continuous forest.

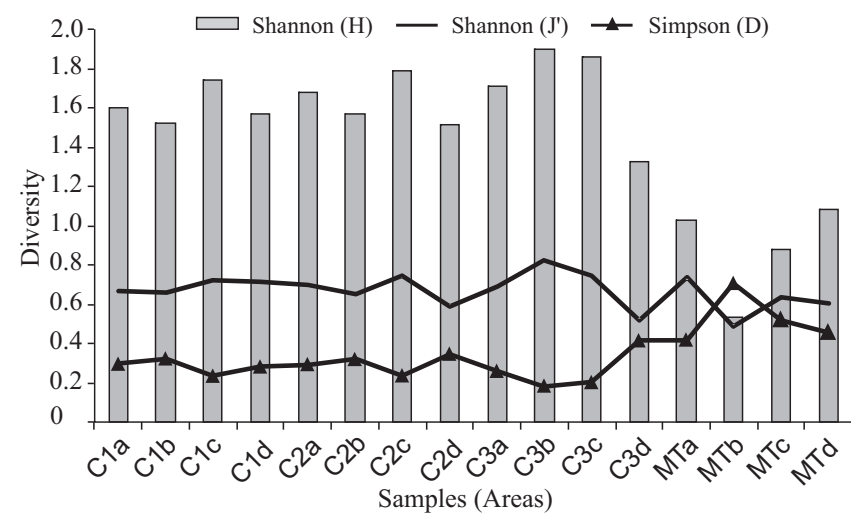

Fig. 3. Diversity of flesh flies at the 16 sample points in the Urucu oilfield in Coari, Amazonas, Brazil.

While the flesh flies were only half as abundant as the blow flies within the study area, their species richness was fifty percent higher, and they presented an inverse pattern of diversity, with higher levels of diversity in the more disturbed habitats. In the same study area, Sousa et al. (2011) recorded a similar pattern in the abundance and richness of flesh flies, indicating that these flies are better adapted to more anthropogenic habitats, with reduced cover. The resources available in these environments tend to be more ephemeral, implying a competitive advantage for rapidly-developing species, such as flesh flies, which are ovoviviparous.

The beta $(\boldsymbol{\beta})$ diversity of the Sarcophagidae. The Jaccard indices (Table III) indicate relatively high levels of similarity among the impacted habitats $(\mathrm{C} 1, \mathrm{C} 2$, and C3), and much lower levels between these habitats and the continuous forest. The NMDS plot (Fig. 4) reinforces this pattern, with $\mathrm{C} 1, \mathrm{C} 2$, and C3 closely grouped, and the continuous forest well separated. The global R value for the ANOSIM (0.3776) was not significant $(\mathrm{p}=0.0014)$, further reinforcing the lack of differentiation among habitats (Table IV and Fig. 4). The results of the NMDS and ANOSIM analyses emphasize not only the distinction between the disturbed habitats and the continuous forest, but also the relative lack of variation among the different types of gaps (C1, C2, and C3).

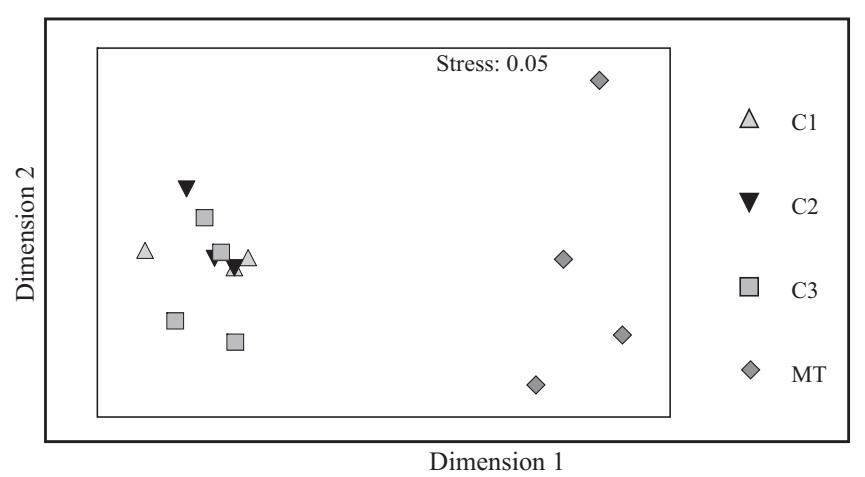

Fig. 4. Non-metric multidimensional scaling (NMDS) of the species composition of the flash-flies communities at 16 sampling points located in the Urucu oilfield, representing four habitat types (C1, C2, C3, and MT). 
The Calliphoridae fauna was more diverse in the betterpreserved habitats (continuous forest and late successional gaps) within the study area at Porto Urucu, in the Brazilian state of Amazonas, whereas the opposite pattern (higher diversity in more impacted habitats) was observed in the Sarcophagidae. While anthropogenic impacts tend to reduce the diversity of blowflies, the diversity of flesh flies is enhanced.

\section{ACKNOWLEDGEMENTS}

We are grateful to the "Evaluation of the dynamics and bio-ecological recuperation of areas impacted by oil exploration" research network in the Urucu basin, and in particular the project "Dynamics of clearings impacted by oil exploration - DICLA", financed by FINEP/CTPETRO, and to CNPq for providing the first author with a masters stipend.

\section{REFERENCES}

Ayres, M.; M. Ayres Jr; D. L. Ayres \& A. S. dos Santos. 2007. BioEstat 5.0 - aplicações estatísticas nas áreas das ciências biológicas e médicas. Belém, Sociedade Civil Mamirauá, 364 p.

Barrantes, G. \& L. Sandoval. 2009. Conceptual and statistical problems associated with the use of diversity indices in ecology. Revista Biología Tropical 57: 451-460.

Centeno, N.; D. Almorza \& C. Arnillas. 2004. Diversity of Calliphoridae (Insecta: Diptera) in Hudson, Argentina. Neotropical Entomology 33: 387-390.

Clarke, K. R.1993. Non-parametric multivariate analyses of changes in community structure. Australian Journal of Ecology 18: 117-143.

Clarke, K. R. \& R. N. Gorley. 2001. Software PRIMER versão 5: User manual/tutorial. Plymouth, PRIMER-E, UK, 91p.

Esposito, M. C.; J. R. P. de Sousa \& F. da S. Carvalho Filho. 2009. Diversidade de Calliphoridae (Insecta: Diptera) em ambientes de matas e próximos de habitações da Estação Científica Ferreira Penna (ECFPn), Melgaço/PA, e da cidade de Portel/PA, p. 461-469. In: P. L. Lisboa (Ed.). Caxiuanã: desafios para a conservação de uma Floresta Nacional na Amazônia. Belém, Museu Paraense Emílio Goeldi, 672 p.

Esposito, M. C.; J. R. P. de Sousa \& F. da S. Carvalho Filho. 2010. Diversidade de Calliphoridae (Insecta: Diptera) na Base de Extração Petrolífera da Bacia do Rio Urucu, na Amazônia brasileira. Acta Amazônica 40: $579-584$

Ferraz, A. C. P.; B. de Q. Gadelha \& V. M. Aguiar-Coelho. 2009. Análise faunística de Calliphoridae (Diptera) da Reserva Biológica do Tinguá,
Nova Iguaçu, Rio de Janeiro. Revista Brasileira de Entomologia 53: 620-628.

Hammer, Ø.; D. A. T. Harper \& P. D. Ryan. 2001. PAST: Paleontological Statistics Software Package for Education and Data Analysis. Paleontologia Electronica 4. Available in: http://www. paleoelectronica. org/2001_1/past/issue1_01.htm (accessed in 10 ${ }^{\text {th }}$ October 2007).

Lawton, J. H.; D. E. Bignell; B. Bolton; G. F. Bloemers; P. Eggleton; P. M. Hammond; M. Hodda; R. D. Holt; T. B. Larsen; N. A. Mawdsley; N. E. Stork; D. S. Srivastava \& A. D. Watt. 1998. Biodiversity inventories, indicator taxa and effects of habitat modification in tropical forest. Nature 391: 72-76.

Legendre, P. \& L. Legendre. 1998. Numerical Ecology. 2 Ed., Amsterdam, Elsevier, 851p.

Lima, S. de O. F. \& D. A. P. do Rosário. 2008. História e Conservação, p. 25-35. In: Lima, S. de O. F.; M. B. Martins; A. L. C. Prudente; L. F. A. Montag; M. C. Monnerat; P. R. Cabral \& D. A. P. do Rosário (Orgs.). Biodiversidade na Província petrolífera de Urucu. Rio de Janeiro, CENPES - Petrobras, 197 p.

Magurran, A. E. 2004. Measuring Biological Diversity. Oxford, Blackwell Science Ltd., 256 p.

Marinoni, R. C. \& N. G. Ganho. 2006. A diversidade diferencial beta de Coleoptera (Insecta) em uma paisagem antropizada do Bioma Araucária. Revista Brasileira de Entomologia 50: 64-71.

McAleece, N.; P. J. D. Lambshead \& G. L. J. Paterson. 1997. BioDiversity Pro (Version 2). London, The Natural History Museum \& The Scottish Association for Marine Science. Available in: http://www.sams.ac.uk/ research/software/bdpro.zip/view (accessed 12 November 2007).

Moreno, C. E. \& G. Halffter. 2001. Spatial and temporal analysis of $\alpha, \beta$ and $\gamma$ diversities of bats in a fragmented landscape. Biodiversity and Conservation 10: $367-382$.

Ovreas, L. \& V. Torsvik, 1998. Microbial diversity and community Structure in two different agricultural soil communities. Microbial Ecology 36: 303-315.

Sousa, J. R. P. de; M. C. Esposito \& F. da S. Carvalho Filho. 2010. Composição, abundância e riqueza de Calliphoridae (Diptera) das matas e clareiras com diferentes coberturas vegetais da Base de Extração Petrolífera, bacia do Rio Urucu, Coari, Amazonas. Revista Brasileira de Entomologia 54: 270-276.

Sousa, J. R. P. de; M. C. Esposito \& F. da S. Carvalho Filho. 2011. Composition, Abundance and Richness of Sarcophagidae (Diptera: Oestroidea) in Forests and Forest Gaps with Different Vegetation Cover. Neotropical Entomology 40: 20-27.

Staddon, W. J.; L. C. Duchesne \& J. T. Trevors, J. T. 1997. Microbial diversity and community structure of postdisturbance forest soils as determined by sole-carbon-source utilization patterns. Microbial Ecology 34: 125-130.

Triplehorn, C. A. \& N. F. Johnson.2011. Estudo dos insetos - tradução da $7^{a}$ edição de borror and delong's introduction to the study of insects. São Paulo, Cengage Learning, 809 p.

Zar, J. H. 1999. Biostatistical analysis. 4 Ed, New Jersey, Prentice Hall International, $660 \mathrm{p}$.

Received 19/2/2011; accepted 12/7/2011

Editor: Rodrigo Krüger 